\title{
Water Quality Assessment in the Nile River, Damietta Branch, Egypt
}

\author{
El-Sayed A. Badr ${ }^{1 *}$, Mervat A. El-Sonbati ${ }^{1}$ and Hossam M. Nassef ${ }^{2}$ \\ ${ }^{1}$ Environmental Sciences Department, Faculty of Science, Damietta University, New Damietta City, Egypt \\ ${ }^{2}$ Chemistry Department, Faculty of Science, Damietta University, New Damietta City, Egypt
}

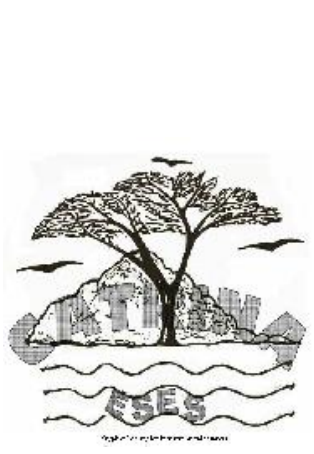

\begin{abstract}
Water is one of the most important inputs for economic development. Management of water quality and control of water pollution and environmental protection are major issues to sustain living conditions. Recently, pollution of the Nile has increased due to increasing of population and related anthropogenic activities. Moreover, Egypt has been listed among the ten countries to be scarce of water by the year 2025 due to the rapidly increasing population. In this study, evaluation of water quality was carried out at two different governorates Dakahlia and Damietta. To evaluate the water quality of the Nile RiverDamietta branch, twenty four water samples have been collected and analyzed for its physico-chemical characteristics including some heavy metals. Data obtained revealed the presence of high concentration of BOD, COD, ammonia, nitrite, nitrate and phosphate as well as dissolved organic matter in the Nile at Damietta district compared to Dakahlia district. In the mean time, measured heavy metals (Fe, $\mathrm{Mn}$ and $\mathrm{Pb}$ ) were recorded in high concentration than permissible limits of Egyptian and WHO standards. Consequently, concentrations of major chemical elements in the Nile water were correlated with the distance downstream from the source of the river, with water in the upstream reaches of good quality, but were relatively polluted at the estuary, supported by the results of water quality index (WQI). Therefore, evaluation of water quality and its management is in need to be done at regular intervals.
\end{abstract}

Key words: Damietta Branch, DOC, DON, Nile river, Nutrients, Water quality.

\section{INTRODUCTION}

Today the competition for scarce water resources is intense at many places all over the world. Many river basins do not have enough water to meet all the demands or even enough for their rivers to reach the terminal lake or sea (Liu and Xia, 2004). Water pollution is one of major world environmental problems, which results from increased population growth, urbanization, and industrialization since the 1990s (Chapman, 1996; Ma et al., 2009). Where, rivers worldwide serve as the recipients of great quantities of waste discharged by agricultural, industrial and domestic activities (Ravindra et al., 2003; Muller et al., 2008).

The Nile River is considered as the main source of freshwater in Egypt. Egypt is unique among other countries in its dependence on very confined share of the surface water of the Nile River. The 1959's Nile water agreement with Sudan, allocates 55.5 BCM (billion cubic meters)/ year to Egypt (MWRI, 2010).

Nile River has been used in a variety of purposes including drinking (domestic) water supply, agricultural irrigation, industrial uses, fisheries, navigation, recreation and others. Water requirements in Egypt are continuously increasing due to growing population, increasing urbanization, industrialization and the rapid agricultural growth. Demands for the agricultural sector represent the largest component (about $80 \%$ ) of the total water demand in Egypt. By the year 2020, water requirements will most likely increase by $20 \%$ (15 $\mathrm{BCM} / \mathrm{yr}$ ) (MWRI, 2010). Moreover, all water uses require that water quality falls within permissible standards specified to that use.

Nile Water pollution is considered one of the greatest water-related challenges facing Egypt which may be attributed to increase agriculture projects, urbanization and industrial developments (Ali et al., 2011). As the urbanization and industrial process continues, water pollution problems have become increasingly evident and have led to serious ecological and environmental problems.

The cost of the environmental degradation due to water pollution is relatively high with serious health and quality of life consequences; as well as increasing the severity of water scarcity problems. Hence, Increasing water pollution causes not only the deterioration of water quality but also threatens human health and the balance of aquatic ecosystems, economic development and social prosperity (Zyadah, 1996). The closed water system of Egypt makes it more vulnerable to quality deterioration in a northward direction toward the Nile Delta (Abdel-Dayem, 2011).

The water quality of Lake Naser and the main stem of the Nile River from Aswan to Cairo are relatively good; with traces of pollutant below the levels set in the quality standards set by Law 48 (Abdel-Dayem, 2011). However, water quality in the irrigation and drainage canals deteriorates downstream and reaches alarming levels in the Nile Delta (Rosette and Damietta branches). Damietta Branch of the Nile receives polluted water of a number of agricultural drains, industrial effluents, domestic sewage as well as urban runoff (Abdel Wahaab and Badawy, 2004; El-Ezaby et al., 2010).

Consequently, management of water resources as well as monitoring of water quantity and quality have been considered as a national responsibility for achieving sustainable development in Egypt. In order to address the pollution problem, it was considered necessary to understand the characteristic of the Nile River system and analyze its water quality. Comparing the obtained results with International and Egyptian standards will 
give an idea about how pollution affects the system. Therefore our study was designed to assess the water quality in 24 Sites allocated in Damietta Branch of the Nile (both Dakahlia and Damietta districts) through analysis of the physio-chemical characteristics of water and calculating water quality index.

\section{Study area and hydrogeology}

The Nile River is considered as one of the longest rivers in the world. It has a total length of about 6700 $\mathrm{km}$; its length inside Egypt is approximately $1352 \mathrm{~km}$. The Nile River travels $940 \mathrm{~km}$ behind the Aswan High Dam, and divides at El-Qnater barrage, into two branches, the Rosette branch which occupied the western and the eastern branch is Damietta.

The Nile Delta is enclosed between the two branches. The Nile Delta holds ecological and economic values and is a major centre of population and agriculture (Elewa, 2010). Damietta branch begins at the Delta Barrage and ends $220 \mathrm{~km}$ downstream at Damietta Dam near Damietta city (APRP, 2002).

The Nile River passes through several climatic zones and various geologic settings. Consequently the Nile has the highest dissolved salt content of any of the African rivers (Dekov et al., 1997). Construction of the Aswan High Dam in 1960's and increased human activities in the Nile valley have dramatically changed the chemistry and mineralogy of the river flux. For instance, most of the sediments carried by the river are entrapped behind the dam and consequently resulted in coastal erosion, wetland loss and salt water intrusion (Elewa, 2010).

The Nile River drains of the African content; it extends from the equatorial climate around Lake Victoria to the Mediterranean climate at its delta. The source of the Nile River is Lake Victoria, but the drainage basins of these great rivers include the rivers that flow into lakes of Victoria, George, Edward and Albert.

Some tributaries join the main stream of the river in its upper reaches and above Khartoum the river is known as the white Nile (descends over $500 \mathrm{~m}$ from the east African plateau to the Sudan plains), the blue Nile draining the high lands of Ethiopia, joins the white Nile at Khartoum (Ahmed and Ismail, 2008).

\section{MATERIALS AND METHODS}

Monitoring of the river water quality is very important for the management of water resources in the drainage basin of the Nile River. Water samples were collected from the Nile River during May 2010 and tested for physical qualities and chemical contents.

The samples were collected from 24 sampling stations along the main flow of the River in both Dakahlia and Damietta districts (Fig. 1) starting from upstream near Banha to downstream near Ras El-Bar. Of the 24 sampling stations, 21 sample sites represent Nile River at Dakahlia and Damietta regions, the rest of sample sites (three sites) represent the Nile Estuary. Geographical location of samples has been recorded using global positioning system (GPS). Water samples were collected from the central area of each site at depth of $20-30 \mathrm{~cm}$.

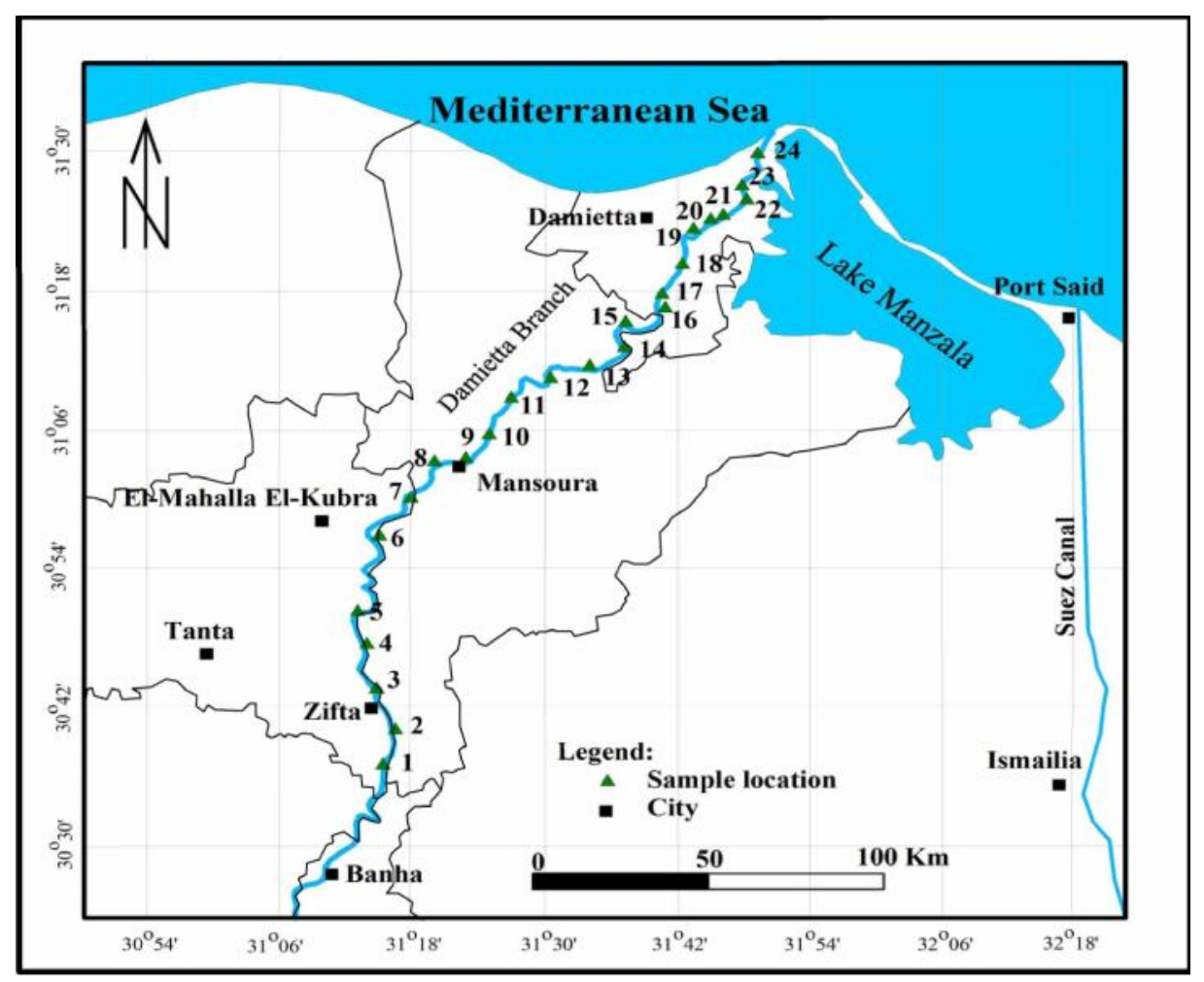

Figure (1): Geographic map of the Nile River (Damietta Branch) indicating location of the 24 sampling stations (stations 1 - 12 at Dakahlia Governorate, 13 - 24 at Damietta Governorate). 
In situ measurements of $\mathrm{pH} /$ temperature were performed using a $\mathrm{pH}$ meter (model HI 8314, Hanna Instruments Ltd). Conductivity, TDS and salinity were measured using Sensions Portable Conductivity Meter (Hach). Dissolved oxygen (DO) was fixed in the field and measured back in the laboratory along with biochemical oxygen demand (BOD) after 5-days as incubation period. Standard methods were adapted for the analysis of various water quality parameters; according to the Standard Method for the Examination of Water and Wastewaters of the American Public Health Association (Adams, 1990; APHA, 2005).

Water quality parameters analyzed in the laboratory were turbidity; chloride, DO, BOD, chemical oxygen demand (COD), dissolved organic carbon (DOC), ammonium, nitrite, nitrate, total nitrogen content, phosphate, total phosphorous, silica and some heavy metal ( $\mathrm{Fe}, \mathrm{Cu}, \mathrm{Pb}, \mathrm{Mn}, \mathrm{Cd}$ and $\mathrm{Zn}$ ). Collected water samples were filtered with Whatman GFF back in the laboratory before analysis of DOC, DON and nutrients. Heavy metals were determined using flame atomic absorption spectrophotometer. Dissolved organic nitrogen (DON) was calculated as difference between the measured total dissolved nitrogen (TDN) and inorganic nitrogen. In the same manner, dissolved organic phosphorus (DOP) was calculated through subtraction of the measured reactive phosphate from total dissolved phosphorus. In recent years; water quality assessment has been performed on the basis of water quality standards for surface water. The water quality index (WQI) is a simple mathematical model used to transform large quantities of water quality data into a single number which summarize different water quality characteristics (Smith 1990; Gupta et al., 2003).

The WQI proposed in this work is composed of some measurable parameters namely; temperature, $\mathrm{pH}$, turbidity, DO, BOD, COD, ammonium, nitrite, nitrate, and total phosphorus; based on the consulting a wide range of literature reviews (Pesce and Wunderlin, 2000; Gupta et al. 2003; Simoes et al., 2008; Seilheimer et al. 2009). The water quality index was calculated for each sampling point using the following empirical equation in order to evaluate water quality (Pesce and Wunderlin, 2000).

$$
\mathrm{WQI}=\mathrm{k} \quad \frac{\sum_{\mathrm{i}} \mathrm{C}_{\mathrm{i}} \mathrm{w}_{\mathrm{i}}}{\sum_{\mathrm{i}} \mathrm{w}_{\mathrm{i}}}
$$

Where, $\mathrm{k}$ is a subjective constant representing the visual impression of river water quality. WQI is usually ranges from 25 (highly polluted water) to a maximum value of 100 (excellent water quality). $\mathrm{Ci}$ is the value assigned to each measured parameter after normalization on a scale from 0 to 100 (Table 1). Zero indicates water that is not suitable for the intended use and 100 represents perfect water quality.

$\mathrm{Wi}$ is the relative weight assigned to each parameter. A maximum weight of 4 was assigned to parameters of relevant importance for aquatic life such as DO and ammonium, while the minimum value (unity) was assigned to parameters with minor relevance such as temperature and $\mathrm{pH}$ (Sanchez et al., 2007). These normalized values are then calculated into a statement of water quality depending on equation (1), which represented as excellent, good, medium, bad and very bad. In this work, the constant $\mathrm{k}$ was not considered in order not to introduce a subjective evaluation (StambukGiljanovic, 1999).

\section{RESULTS AND DISCUSSION}

The initial evaluation of the obtained results has been carried out via the comparison of data of the current study with the Egyptian Environmental Regulations Law No. 48 of 1982 (Table 2). The physico-chemical characteristics provide fair idea of the water quality for any water body.

Table (1): Parameters considered in the water quality index calculation adapted from (Pesce and Wunderlin, 2000), (Sanchez et al., 2007) and (Simoes et al., 2008).

\begin{tabular}{|c|c|c|c|c|c|c|c|c|c|c|c|c|}
\hline \multirow[t]{2}{*}{ Parameters } & \multirow[t]{2}{*}{ Wi } & \multicolumn{11}{|c|}{ Normalization factor $\mathbf{C i}$} \\
\hline & & $\mathbf{0}$ & 10 & 20 & 30 & 40 & 50 & 60 & 70 & 80 & 90 & 100 \\
\hline $\mathrm{pH}$ & 1 & $1-14$ & $2-13$ & $3-12$ & $4-11$ & $5-10$ & $6-9.5$ & $6.5-7$ & $7-9$ & $7-8.5$ & $7-8$ & 7 \\
\hline Temperature & 1 & $>45 /<-6$ & $45 /-6$ & $40 /-4$ & $36 /-2$ & $32 / 0$ & $30 / 5$ & $28 / 10$ & $26 / 12$ & $24 / 14$ & $22 / 15$ & $21 / 16$ \\
\hline Turbidity & 2 & $>100$ & $\unlhd 00$ & $<80$ & $<60$ & $<40$ & $<30$ & $<25$ & $<20$ & $<15$ & $<10$ & $<5$ \\
\hline DO & 4 & $<1.0$ & $\geq 1.0$ & $>2.0$ & $>3.0$ & $>3.5$ & $>4.0$ & $>5.0$ & $>6.0$ & $>6.5$ & $>7.0$ & $\geq 7.5$ \\
\hline BOD-5 & 3 & $>15$ & $\unlhd 5$ & $<12$ & $<10$ & $<8$ & $<6$ & $<5$ & $<4$ & $<3$ & $<2$ & $<0.5$ \\
\hline COD & 3 & $>150$ & $\leq 50$ & $<100$ & $<80$ & $<60$ & $<50$ & $<40$ & $<30$ & $<20$ & $<10$ & $<5$ \\
\hline Ammonium & 4 & $>1.25$ & $\leq 1.25$ & $<1.00$ & $<0.75$ & $<0.50$ & $<0.40$ & $<0.30$ & $<0.20$ & $<0.10$ & $<0.05$ & $<0.01$ \\
\hline Nitrite & 2 & $>1.00$ & $\leq .00$ & $<0.50$ & $<0.25$ & $<0.20$ & $<0.15$ & $<0.10$ & $<0.05$ & $<0.03$ & $<0.01$ & $<0.005$ \\
\hline Nitrate & 2 & $>100$ & $\leq 00$ & $<50$ & $<20$ & $<15$ & $<10$ & $<8.0$ & $<6.0$ & $<4.0$ & $<2.0$ & $<0.5$ \\
\hline T. Phosphorus & 1 & $>0.30$ & $<0.30$ & $<0.20$ & $<0.175$ & $<0.15$ & $<0.125$ & $<0.10$ & $<0.075$ & $<0.05$ & $<0.025$ & $<0.025$ \\
\hline
\end{tabular}

All values, except $\mathrm{pH}$ and temperature, in $\mathrm{mg} / \mathrm{l}$; $\mathrm{Wi}$ is the relative weight. 

Table (2): Egyptian standard regularities of article $60-$ law No. 48/1982 regarding minimum standards for the water quality of the Nile River.

\begin{tabular}{cccc}
\hline \hline Parameter & $\begin{array}{c}\text { Egyptian } \\
\text { Regulation } \\
(\mathbf{m g} / \mathbf{l})\end{array}$ & Parameter & $\begin{array}{c}\text { Egyptian } \\
\text { Regulation } \\
(\mathbf{m g} / \mathbf{l})\end{array}$ \\
\hline Temperature & $\begin{array}{c}\text { Over usual by } \\
5 \mathrm{C}^{\mathrm{o}}\end{array}$ & Nitrate & 45 \\
\hline $\mathrm{pH}$ & $7.0-8.5$ & Iron & 1 \\
\hline $\mathrm{TDS}$ & 500 & Manganese & 0.5 \\
\hline $\mathrm{DO}$ & $>=5$ & Copper & 1 \\
\hline BOD & 6 & Zinc & 1 \\
\hline COD & 10 & Cadmium & 0.01 \\
\hline DON & 1 & Lead & 0.05 \\
\hline Ammonium & 0.5 & & \\
\hline \hline
\end{tabular}

\section{Physico-Chemical Characteristics}

The surface water temperature of the collected water samples ranged from 22.1 to $29{ }^{\circ} \mathrm{C}$; the variation is associated with sampling time. Temperature is basically important for its effects on certain chemical and biological reactions taking place in water and aquatic organisms (Chapman ,1996).

It depends upon different parameters such as the season, time of sampling and also upon the temperature of waste water effluents which added into the river. Temperature affects the solubility of gases in water such as oxygen. Elevated temperature can adversely affect the aquatic flora and fauna.

$\mathrm{pH}$ is an important indicator of water quality and the extent of pollution (Jonnalagadda and Mhere, 2001). The water in Nile River was slightly alkaline throughout the study area; with an average value of 8.11 . The minimum $\mathrm{pH}$ value was 7.73 and recorded at Site 17. However, maximum $\mathrm{pH}$ was 8.8 and recorded at Site 24 . This data is in agreement with data recorded by (Chapman, 1996), in which the suitable $\mathrm{pH}$ range for the growth of aquatic life ranged from $\mathrm{pH} 6.5$ to 9.

Electrical conductivity (EC) measured in the collected samples revealed that the EC increased along the downstream of the river. The EC values ranged from 308 to $469 \mu \mathrm{s} / \mathrm{cm}$ for fresh water samples $(1-21)$; whereas average values for saline water samples (sites 22 to 24) was $52.1 \times 103 \mu \mathrm{s} / \mathrm{cm}$. Total dissolved solids (TDS) are composed of carbonates, bicarbonates, chlorides, sulphates, phosphates and nitrates of $\mathrm{Ca}, \mathrm{Mg}, \mathrm{Na}, \mathrm{K}$, and $\mathrm{Mn}$ and organic matter, salts and others particles.

TDS values for fresh water samples were in the range of $170-248 \mathrm{mg} / \mathrm{l}$; with average highest value of $35.7 \mathrm{x}$ $103 \mathrm{mg} / \mathrm{l}$ for saline water samples. Turbidity values ranged from 0.74 to $6.6 \mathrm{NTU}$, with average value of 2.53 NTU. It is shown that, the turbidity values of all water samples collected lies in the normal ranges of natural water. Chloride is an inert tracer denoting freshwater inputs and provides information on physical processes especially evaporation occurring during recharge and time-dependent flow.
In the present study average concentration of chloride was $22.4 \mathrm{mg} / \mathrm{l}$ for freshwater samples and $24.4 \mathrm{x} 103$ $\mathrm{mg} / \mathrm{l}$ for saline water samples. Highest values of 40.7 $\mathrm{mg} / \mathrm{l}, 248 \mathrm{mg} / \mathrm{l}$, and $313 \mu \mathrm{g} / \mathrm{l}$ for chloride, TDS and ammonium, respectively were observed at sampling site 14 (out of freshwater samples), which might be due to input from agriculture drainage. Ma et al., (2009) reported that high chloride concentration in water along with ammonium nitrogen indicates the presence of organic waste in water, primarily of animal origin.

\section{Organic Matter Indicators (DO, BOD and COD)}

Dissolved oxygen is one of the important parameter in water quality assessment. It is essential to maintain variety of forms of biological life in the water including aquatic fauna and flora. In the present study, the minimum recorded value of DO was $5.46 \mathrm{mg} / \mathrm{l}$ at Site 24 where maximum value was $9.5 \mathrm{mg} / \mathrm{l}$ recorded at Site 10 (Fig. 2).

The level of dissolved oxygen recorded in our sample from the river should be able to support good fauna and flora. It was reported that a minimum of $5 \mathrm{mg} / \mathrm{l}$ dissolved oxygen is necessary for healthy fish and other aquatic life (Chapman, 1996). Relatively higher DO values were reported for water samples collected from Dakahlia district; reflecting a better water quality of this region compared to downstream of Damietta region (Fig. 2).

DO is regulator of metabolic activities of organisms and thus governs metabolism of the biological community as a whole and also acts as an indicator of trophic status of the water body. Dissolved Oxygen is generally reduced in the water due to respiration of biota, decomposition of organic matter, rise in temperature, oxygen demanding wastes and inorganic reducing agent such as hydrogen sulfide, ammonium, nitrites, ferrous iron, etc (Sanchez et al., 2007).

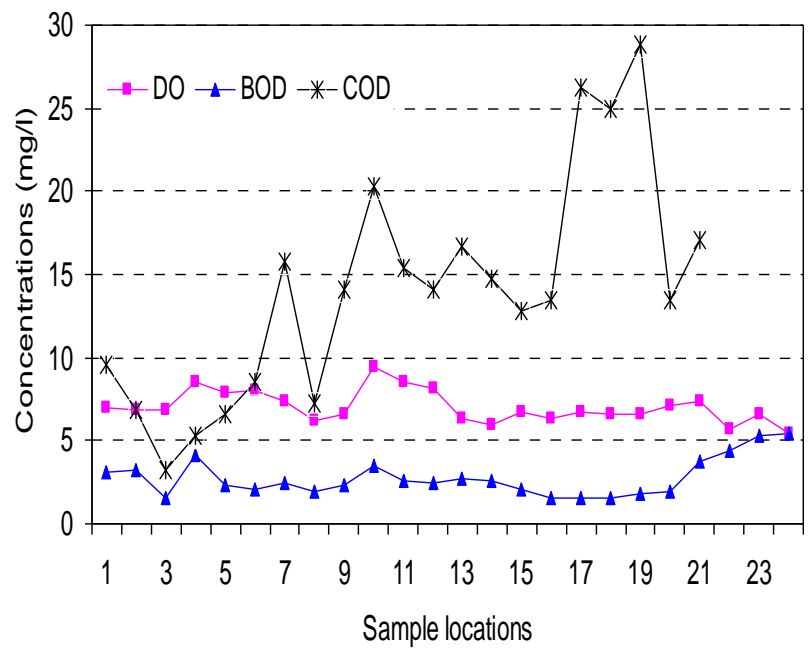

Figure (2): Concentrations of DO, BOD and COD (mg/l) in water samples collected from the Nile River, Damietta Branch. 
Biochemical oxygen demand is an important pollution indicator that reflects the load of organic waste. In our study, values of BOD ranged from 1.54 to $5.40 \mathrm{mg} / \mathrm{l}$, with higher values towards downstream of Damietta region. When organic matter in water is decomposed by aerobic microorganisms, the amount of biologically adsorbed oxygen increased.

Chemical oxygen demand concentrations in the collected freshwater samples ranged from 3.78 to 28.9 $\mathrm{mg} / \mathrm{l}$. COD gives us a reliable parameter for judging the extent of organic pollution in water COD is the measure of the oxygen required for chemical oxidation of organic matter.

In concern to our study, relatively higher values of BOD and COD were reported for water samples collected from Damietta district compared to those collected from Dakahlia district (Fig. 2). Higher BOD and COD values reflects high load of organic matter due to increased level of pollution in aquatic ecosystem of the Damietta region, which adversely affect the water quality. Average high COD/BOD ratio of 6.65; indicates that high percentage of organic matter might be resistance to microbial degradation.

\section{Nutrients}

Nutrients such as nitrogen and phosphorus $(\mathrm{N}, \mathrm{P})$ are essential macro-nutrients for the growth of aquatic fauna and flora; but excess inputs of nutrients can lead to eutrophication problems (Varol and Sen, 2012).

The average concentration of ammonium in the collected water samples is $124 \mathrm{mg} / \mathrm{l}$ with highest value of $313 \mathrm{mg} / \mathrm{l}$ reported at sampling Site 14 (Fig. 3). Ammonium is mostly produced by decomposition of organic matter and by hydrolysis of urea (El-Sheltawy et al., 2007). Relatively higher values of ammonium were reported for water samples collected from Damietta district; reflecting anthropogenic sources of pollution downstream in the region of Damietta governorate (Fig. 3). Generally, the presence of high levels of ammonium is an evidence of sewage inflow into a water body.

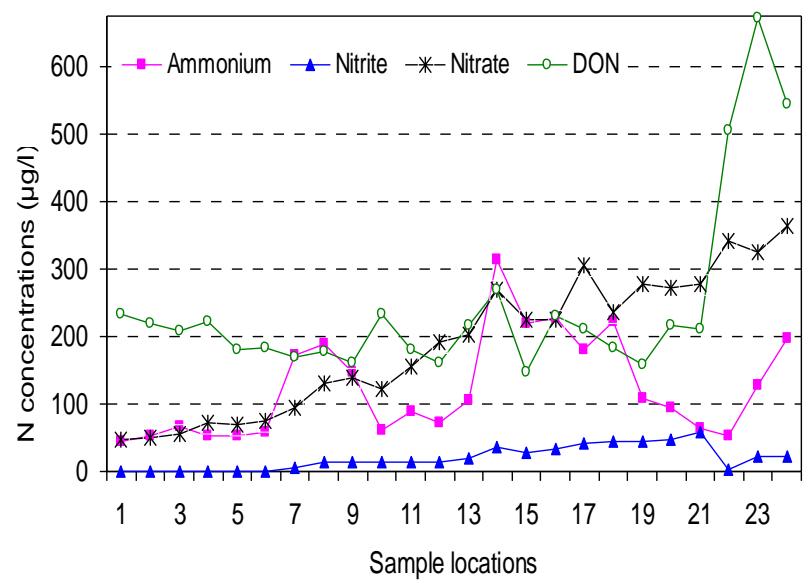

Figure (3): Concentrations of nitrogen species $(\mu \mathrm{g} / \mathrm{l})$ in water samples collected from the Nile River, Damietta Branch.
Nitrate is the final stable form of oxidation / decaying of organic matter from domestic, industrial and agricultural sources. Average nitrate concentrations in the collected water samples was $189 \mu \mathrm{g} / \mathrm{l}$, with highest value of $363 \mu \mathrm{g} / \mathrm{l}$ recorded at site 24 .

As shown in figure (3) nitrate levels increased from upstream towards downstream; reflecting good water quality of the Nile at Dakahlia governorate, whereas the Nile at Damietta district might be subjected to various sources of water pollution.

Nitrite is an intermediate compound in both the oxidation (nitrification) of ammonium to nitrate and reduction (de-nitrification) of nitrate to nitrogen gas. Nitrite concentrations in the Nile River ranged from 0.42 to $58.4 \mu \mathrm{g} / \mathrm{l}$; with average value of $19.9 \mu \mathrm{g} / \mathrm{l}$. Nitrite is not stable and its presence in higher concentrations generally indicates that changes are in progress (Awadallah and Moalla, 1996).

In the present study, phosphate values ranged from 8.46 to $93.02 \mu \mathrm{g} / \mathrm{l}$; with average value of $31.2 \mu \mathrm{g} / \mathrm{l}$ (Fig. 4). Total phosphorus in collected water samples ranged from 50.7 to $116 \mu \mathrm{g} / \mathrm{l}$. Generally, major anthropogenic sources of phosphate in water are domestic sewage, agriculture effluents and industrial waste waters. Reactive phosphate is easily utilized by primary producers (Monbet et al., 2009).

Relatively higher values of phosphate and total phosphorus were reported for freshwater samples collected from Damietta district; compared to those collected from Dakahlia district (Fig. 4). Highest values of ammonium, phosphate and total phosphorus were reported at station 14; reflecting agricultural drainage at this site.

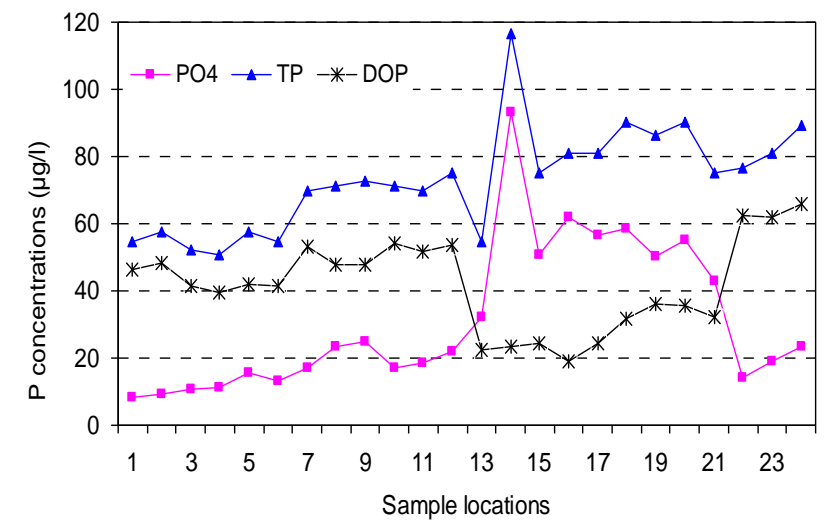

Figure (4): Concentrations of phosphorus species $(\mu \mathrm{g} / \mathrm{l})$ in water samples collected from the Nile River, Damietta Branch.

Silica concentrations in the collected water samples ranged from 0.75 to $2.6 \mathrm{mg} / \mathrm{l}$ (Fig. 5). Silicate is an essential limiting nutrient for growth of diatoms, the rigidity of plant and fish tissues (Robards et al., 1994). The major source of dissolved silica in river is the weathering of rocks and mineral in the catchments area. Although, silica is quite abundant on the earth, however silicates remain deficient in water. 


\section{Dissolved Organic Matter (DOC, DON AND DOP)}

DOC concentrations in water samples collected from the Nile (Damietta Branch) ranged from 1.40 to 6.52 $\mathrm{mg} / \mathrm{l}$, with average value of $3.35 \mathrm{mg} / \mathrm{l}$ (Fig. 5). Relatively higher values of DOC reflect high organic load due to extensive anthropogenic activities within the study area.

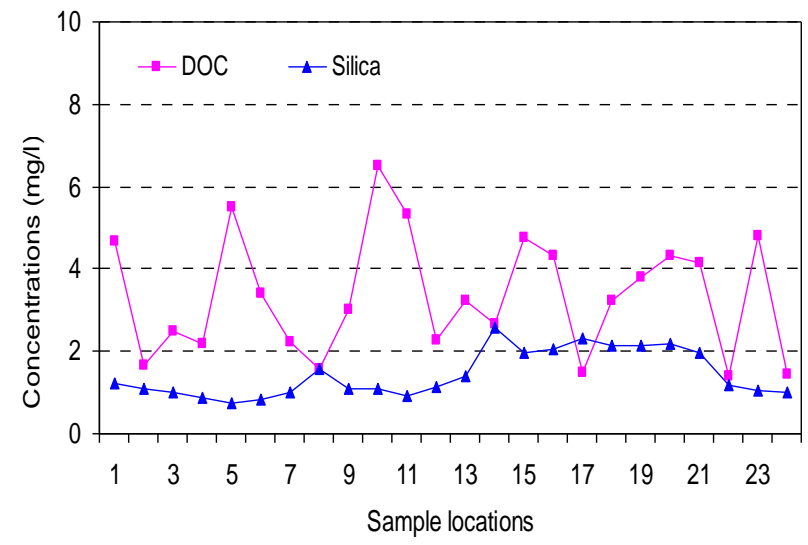

Figure (5): Concentrations of silica and DOC (mg/l) in water samples collected from the Nile River, Damietta Branch.

DON concentrations in the collected water samples ranged from 148 to $671 \mu \mathrm{g} / \mathrm{l}$; with average value of 246 $\mu \mathrm{g} / \mathrm{l}$. As shown in figure 3 , highest values of DON were recorded for saline water samples collected from downstream at Damietta City (sites 22, 23 and 24). The enhanced DON values for the Nile Estuary at Damietta region might be attributed to sewage discharges, boating activities and other anthropogenic activities. Values of DOP in the collected water samples ranged from 18.8 to $65.8 \mu \mathrm{g} / \mathrm{l}$, with average concentration value of $42 \mu \mathrm{g} / \mathrm{l}$.

The amount of DON as a percentage of TDN pool was ranged between 23.9 and $71.5 \%$ for the Nile, Damietta Branch. Percentages of DOP/TP of the collected water samples were in the range $20.1-84.6 \%$ (Fig. 6).

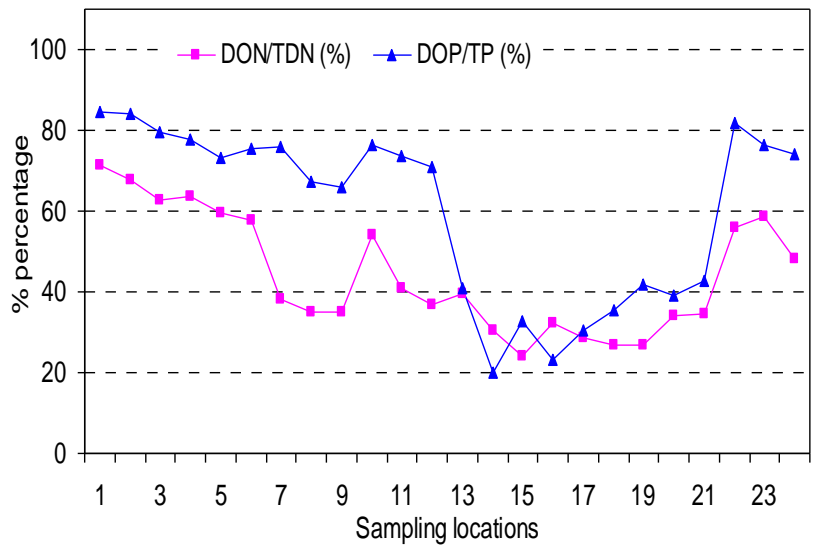

Figure (6): The percentage of DON/TDN and DOP/TP in water samples collected from the Nile River, Damietta Branch.

Lower percentage values of DON/TDN and DOP/TP recorded for fresh water samples collected from the Nile at Damietta district (sites 14 - 21) may be due to higher values of ammonium and phosphate at these locations consequently. Hence, considerations of DON and DOP biogeochemistry in water quality assessment and monitoring are essential as the omission of DON and DOP in natural water studies will result in underestimation of $\mathrm{N}$ and $\mathrm{P}$ load and subsequently result in an underestimation of eutrophication pressures on local and regional aquatic environment (Bronk, 2002).

\section{Water Quality Index}

WQI promotes adequate classification of water quality and allow the public and decision makers to receive water quality information (Pesce and Wunderlin, 2000). According to Sanchez et al., 2007, WQI is classified as follows: 0 - 25 (very bad), 26 - 50 (bad), 51 - 70 (medium), 71 - 90 (good) and finally 91 - 100 (excellent). Figure 7 shows, the water quality index calculated using equation 1. Normalized factors are described in Table1. WQI indicates better water quality of the Nile water at Dakahlia district (WQI ranges 85 92) than water quality of the Nile at Damietta district (WQI ranges 73 - 85).

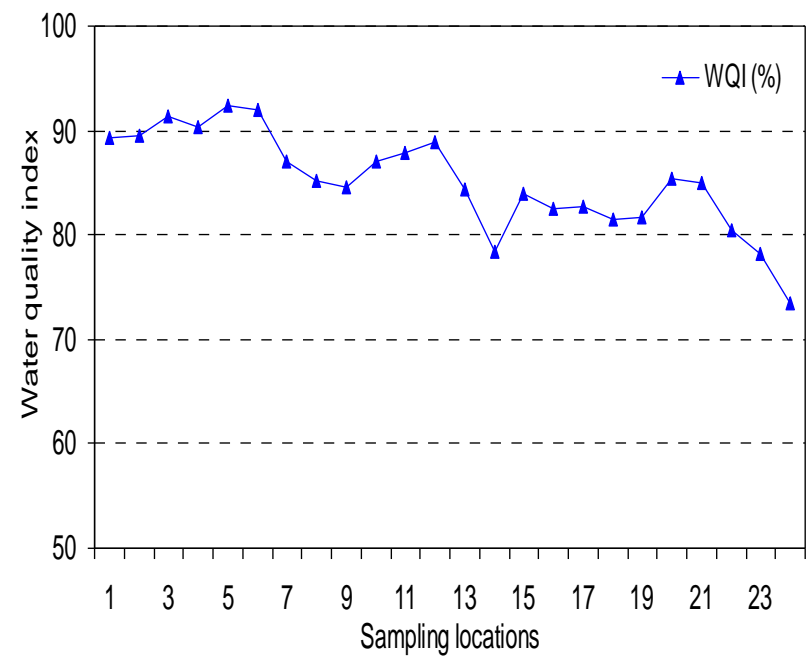

Figure (7): Values of water quality index (WQI) in water samples collected from the Nile River, Damietta Branch.

Lowest values of WQI were reported at sampling site 14 as well as estuarine water samples (22 - 24). Overall, the results of WQI indicate that the Nile water quality of the studied area classified as good (WQI average 85). (Sanchez et al., 2007) revealed an acceptable level of water quality (medium to good of WQI) for the Manzanares River and the Paris Park watersheds.

The current values of WQI (73 - 92) are higher than WQI values (62 - 76.5) reported by El-Ezaby et al, 2010; indicating the improvement of water quality with time after removal of fish cages. Thus the use of WQI can give a significant indication of the Nile water quality and keep tracks of any changes overtime.

\section{Heavy Metals}

Living organisms require trace amounts of some heavy metals, whereas excessive levels could be detrimental 
(Muller et al., 2008; Varol and Sen, 2012). Heavy metals can enter rivers and streams from different sources, including natural and anthropogenic sources within the catchments and directly from effluent discharges.

Determined concentration of iron $(\mathrm{Fe})$ in the water samples for the present study ranged from 0.168 to 2.78 $\mathrm{mg} / \mathrm{l}$ with average value of $0.836 \mathrm{mg} / \mathrm{l}$. The recorded higher values of iron exceeded the permissible limit of iron $(1 \mathrm{mg} / \mathrm{l})$ recommended by Egyptian standards (Article 60 -law No. 48/1982). However, manganese (Mn) concentrations in the collected water samples ranged between 0.533 to $1.17 \mathrm{mg} / \mathrm{L}$ with an average value of $0.912 \mathrm{mg} / \mathrm{l}$. The measured $\mathrm{Mn}$ concentrations were found to be within the range of permissible limit (1 $\mathrm{mg} / \mathrm{l})$.

The values of copper $(\mathrm{Cu})$ concentrations in the collected water samples ranged from 0.022 to 0.217 $\mathrm{mg} / \mathrm{l}$. Lower concentration of copper may be due to its tendency to form complexes with organic matter, where about $90 \%$ of $\mathrm{Cu}$ in water could form a complex with humic matter (Zyadah ,1996). Zinc (Zn) concentrations ranged from lower value of $0.07 \mathrm{mg} / \mathrm{l}$ to higher values up to $0.975 \mathrm{mg} / \mathrm{l}$ with an average value of $0.449 \mathrm{mg} / \mathrm{l}$. From the hydro-biological point of view, the relative decrease in zinc concentration may be attributed to the decrease in the decomposition rate of organic matter and the consumption of this metal by phytoplankton. The mean value of cadmium $(\mathrm{Cd})$ concentrations averaged $0.132 \mathrm{mg} / \mathrm{l}$, and ranged from 0.012 to $0.463 \mathrm{mg} / \mathrm{l}$. However, these values exceed the allowable limits of cadmium $(0.01 \mathrm{mg} / \mathrm{L})$. The higher values recorded for cadmium may be due to agricultural, domestic and industrial wastewaters discharged into Nile River. It was found that $70-90 \%$ of $\mathrm{Cd}$ in a fresh water stream was present as the free hydrated ion or other liable complexes. In general, a high proportional of $\mathrm{Cd}$ is usually associated with organic matter, particularly humic acid (Giller et al., 1998). Lead (Pb) concentrations in the collected water samples ranged from 0.118 to 1.54 $\mathrm{mg} / \mathrm{l}$, with average value of $0.34 \mathrm{mg} / \mathrm{l}$. The reported lead values in the current study are much higher than the permissible limit where, the standard limit of lead for domestic and irrigation water is $0.05 \mathrm{mg} / \mathrm{L}$. It was found that the potential pollutants resulting from industrial drainage, domestic sewage, agricultural drainage and urban runoff lead to increase of heavy metal concentration in water.

\section{Correlation Coefficients for Water Parameters}

Correlations (Pearson's product moment) between pairs of water quality parameters were calculated using SPSS in order to identify statistically significant correlations (at the 95 - 99\% confidence level), and thus aid interpretation of the data (Table 3). Significant positive correlations between pairs of water quality parameters mean proportional relationships. However, significant negative correlations reflect interlocking and counteraction between the measured parameters; one variable tends to decrease as the other increases (Awadallah and Moalla ,1996; Wu et al., 2012).

As shown in Table 3, a significant positive correlation (99\% confidence) was observed between salinity (TDS) and organic matter indicators including BOD $(r=0.772)$, COD $(r=0.613)$, DON $(r=0.954)$ and DOP $(r=0.615)$; supporting the observation of high concentrations of these parameters in the Nile Estuary at Damietta region. In the same manner, higher concentrations of nitrate, copper, cadmium and lead in the Nile Estuary at Damietta reflect the significant positive correlation between salinity (TDS) and these parameters.

A significant negative correlation $(r=-0.441,95 \%$ confidence) was observed between dissolved oxygen (DO) and salinity (TDS), supporting the fact that the concentrations of dissolved oxygen decrease with increasing salinity. A significant positive correlation was reported between turbidity and iron $(r=0.662,99 \%$ confidence) which might be due to the colloidal behaviour of iron with suspended matter.

A weak but significant negative correlation was found between $\mathrm{pH}$ and ammonium $(r=-0.465,95 \%$ confidence). That might be due to the fact that in acidic water, ammonia $\left(\mathrm{NH}_{3}\right)$ reacts with water to create ammonium ions $\left(\mathrm{NH}_{4}^{+}\right)$and hydroxyl $\left(\mathrm{OH}^{-}\right)$ions. When water is basic, the reaction goes in the opposite way; ammonia $\left(\mathrm{NH}_{3}\right)$ and water $\left(\mathrm{H}_{2} \mathrm{O}\right)$ are separately released via splitting of hydroxyl ions $\left(\mathrm{OH}^{-}\right)$from ammonium $\left(\mathrm{NH}_{4}^{+}\right)$. Generally, ammonia $\left(\mathrm{NH}_{3}\right)$ is much more toxic to aquatic biota than ionized form of ammonium $\left(\mathrm{NH}_{4}{ }^{+}\right)$.

Significant positive correlations ( $99 \%$ confidence) were found between phosphate and inorganic nitrogen species namely ammonium, nitrite and nitrate $(r=0.751$, 0.812 , and 0.558 respectively). Since phosphorus and nitrogen are plant nutrients, they are important ingredients in fertilizers. As rain water washed off fertilized fields, some of the phosphorus and nitrogen are carried into streams and rivers, contributing to eutrophication.

Aquatic organisms involved in biological processes require phosphorus and nitrogen for reproduction and synthesis of new cell tissue. Similarly, significant positive correlations (99\% confidence) were found between silica and other nutrients species including phosphate $(r=0.932)$, ammonium $(r=0.627)$, nitrite $(r=$ $0.844)$ and nitrate $(r=0.541)$.

Significant negative correlations (99\% confidence) were found between DO and nitrogen species namely TDN, ammonium and nitrate $(r=-0.624,-0.547$ and 0.539 respectively). In aerobic conditions, nitrogenous compounds are biologically oxidized to ammonium, nitrites and nitrates minimizing the dissolved oxygen content in the aquatic environment. 


\section{CONCLUSION}

Physico-chemical characteristics of water including dissolved organic matter, nutrients and heavy metals were measured in water samples collected from the Nile River (Damietta Branch) to assess its quality. Relatively higher concentrations of BOD, COD, nutrients (ammonium, nitrite, nitrate, and phosphate), dissolved organic matter (DOC, DON) and some heavy metals (iron, manganese, and lead) were reported for water samples collected from the Nile at Damietta district, compared to those collected from the Nile at Dakahlia district.

The obtained results indicate relatively better water quality of the Nile up stream at Dakahlia Governorate. Whereas, the Nile at Damietta Governorate is subjected to various sources of pollution such as domestic waste water, industrial discharge, agricultural drains and the undesirable habits of the local people. Thus, the Nile River in the vicinity of Damietta City is under pollution stress from various anthropogenic activities.

The Nile River is the main source of freshwater in Egypt and its water should satisfy the needs of constantly growing population. Protecting and managing the Nile River in the study area is important for achieving sustainable development of natural resources. Protecting water resources can be achieved through the following actions. First, consumption of water should be decreased until it reaches the sustainable level permitted by the available resources. Achieving this goal will require more efficient water use by industry, agriculture, and the area's domestic population. Second, discharge of wastes into the surface water should be drastically reduced so that the ecosystem's natural ability to degrade these wastes will not be exceeded.

This goal can be achieved by modernization of all the industrial, agricultural, and domestic processes that use water, thereby improving the recovery and recycling of waste water, encouraging the use of crops with high water-use efficiency to reduce evapo-transpiration, and encouraging the use of high-efficiency toilets to minimize the amount of sewage that is created.

Third, additional water treatment facilities must be made available, and old facilities need to be upgraded to increase their capacity and improve their efficiency. To create more sustainable means of production, there must be a shift in attitudes toward proactive waste management practices that represent a move away from control measures towards preventative measures in cities and in all industrial sectors. Fourth, establishment of environmental monitoring program should be extended to define water quality of all drains and canals that discharge into the Nile.

\section{Acknowledgements}

The authors would like to thank Department of Environmental Sciences, Faculty of Science, Damietta University in conducting this research. This research was funded by the International Foundation for Sciences (IFS)
Grant NO W/4509-1. The comments of the anonymous reviewers are also gratefully acknowledged.

\section{REFERENCES}

ABDEL-WAHAAB, R., AND M. I. BADAWY. 2004. Water quality assessment of the River Nile system: an overview. Biomedical and Environmental Sciences 17 $87-100$

ABDEL-DAYEM, S. 2011. Water Quality management in Egypt. International Journal of water Resources Development 27 (1): 181 - 202.

ADAMS, V. D. 1990. Water and Wastewater Examination Manual. Lewis Publishers, Michigan, USA.

AHMED, A. A., AND U. H. ISMAIL. 2008. Sediment in the Nile River System. International Hydrological Programme, International Sediment Initiative, UNESCO-IHP, Khartoum, Sudan.

ALI, S. M., S. Z. SABAE, M. FAYEZ, M. MONIB, AND N. A. HEGAZI. 2011. The influence of agroindustrial effluents on River Nile pollution. Journal of Advanced Research 2 (1): 85 - 95.

APHA. 2005. Standard Methods for the Examination of Waters and Wastewaters. American Public Health Association (APHA), Washington, DC, USA.

APRP. 2002. Survey of Nile System Pollution Sources. Agricultural Policy Reform Program (APRP), Ministry of Water Resources and Irrigation, Report No. 64, Cairo, Egypt.

AWADALLAH, R. M., AND S. M. N. MOALLA. 1996. Seasonal variation of High Dam lake water. Journal of Environmental Science and Health Part AToxic/Hazardous Substances and Environmental Engineering 31 (4): 731 - 46.

BRONK, D. A. 2002. Dynamic of DON. In D. A. Hansell, C.A. Carlson [eds.]. Biogeochemistry of Marine Dissolved Organic Matter, 153 -247. Academic press.

CHAPMAN, D. 1996. Water quality assessments- A guide to the use of biota, sediments and water in environmental monitoring. E \& FN SPON An Imprint of Routledege on behalf of UNSCO, WHO and UNEP, London New York.

DEKOV, V. M., Z. KOMY, F. ARAUJO, A. VAN PUT AND R.VAN GRIEKEN. 1997. Chemical composition of sediments, suspended matter, river water and ground water of the Nile (Aswan-Sohag traverse). The Science of the Total Environment 201 (3): 195 - 210.

EL-EZABY, K. H., M. A. EL-SONBATI, AND E. A. BADR. 2010. Impact of fish cages on the Nile water quality at Damietta Branch. Mansoura Journal of Environmental Sciences 39 (3): 329 - 44.

El-Sheltawy, H. M., A. S. Morsy, A. S. El-Lithy, M. A. Labib, S. H. Maree, D. F. Ahmed, E. A. Mohamed, R. M. Saleh, K. H. Korany, AND M. A. Abo El-Azm. 2007. Environmental Monitoring of Water Quality of River Nile 2005 - 2006; Second International Conference on Environmental Engineering. Cairo, Egypt, Ain Shams University. 2007. Ref Type: Conference Proceeding.

ELEWA, H. H. 2010. Potentialities of Water Resources Pollution of the Nile River Delta, Egypt. The Open Hydrology Journal $4: 1$ - 13. 
GILLER, K. E., E. WITTER AND S. P. MCGRATH. 1998. Toxicity of heavy metals to microorganisms and microbial processes in agricultural soils: a review. Soil Biology and Biochemistry 30 (10 - 11): 1389 - 414.

GUPTA, A. K., S. K. GUPTA AND R. S. PATIL. 2003. A comparison of water quality indices for coastal water. Journal of Environmental Science and Health Part AToxic/ Hazardous Substances and Environmental Engineering 38 (11): 2711 - 25.

JONNALAGADDA, S. B. AND G. MHERE. 2001. Water quality of the odzi river in the eastern highlands of zimbabwe. Water Research 35 (10): 2371 - 6.

LIU, C., AND J. XIA. 2004. Water problems and hydrological research in the Yellow River and the Huai and Hai River basins of China. Hydrol. Process. 18 (12): 2197 - 210.

MA, J., Z. DING, G. WEI, H. ZHAO, AND T. HUANG. 2009. Sources of water pollution and evolution of water quality in the Wuwei basin of Shiyang river, Northwest China. Journal of Environmental Management 90 (2): 1168 - 77.

MONBET, P., I. D. MCKELVIE, AND P. J. WORSFOLD. 2009. Dissolved organic phosphorus speciation in the waters of the Tamar estuary (SW England). Geochimica et Cosmochimica Acta 73 (4): 1027 - 38.

MULLER, B., M. BERG, Z. P. YAO, X. F. ZHANG, D. WANG, AND A. PFLUGER. 2008. How polluted is the Yangtze river? Water quality downstream from the Three Gorges Dam. Science of the Total Environment 402 (2-3): 232 - 47.

MWRI. 2010. Water Challenges in Egypt. Ministry of Water Resources and Irrigation (MWRI), Cairo, Egypt.

PESCE, S. F. AND D. A. WUNDERLIN. 2000. Use of water quality indices to verify the impact of Cordoba City (Argentina) on Suquia River. Water Research 34 (11): $2915-26$

RAVINDRA, K., AMEENA., MEENAKSHI, MONIKA. RANI, AND A. KAUSHIK. 2003. Seasonal variations in physico-chemical characteristics of River Yamuna in Haryana and its ecological best-designated use. Journal of Environmental Monitoring 5 (3): 419 - 26.

ROBARDS, K., I. D. MCKELVIE, R. L. BENSON, P. J. WORSFOLD, N. J. BLUNDELL AND H. CASEY.
1994. Determination of Carbon, Phosphorus, Nitrogen and Silicon Species in Waters. Analytica Chimica Acta 287 (3): 147 - 90.

SANCHEZ, E., M.F. COLMENAREJO, J. VICENTE, A. RUBIO, M.G. GARCIA, L. TRAVIESO AND R. BORJA. 2007. Use of the water quality index and dissolved oxygen deficit as simple indicators of watersheds pollution. Ecological Indicators 7 (2): 315 28.

SEILHEIMER, T. S., T .P. MAHONEY AND P. CHOWFRASER. 2009. Comparative study of ecological indices for assessing human-induced disturbance in coastal wetlands of the Laurentian Great Lakes. Ecological Indicators 9 (1): 81 - 91.

SIMOES, F. d. S., A. B. MOREIRA, M. C. BISINOTI, S. M. N. GIMENEZ AND M. J. S. YABE. 2008. Water quality index as a simple indicator of aquaculture effects on aquatic bodies. Ecological Indicators 8 (5): $476-84$

SMITH, D. G. 1990. A better water quality indexing system for rivers and streams. Water Research 24 (10): 1237 - 44.

STAMBUK-GILJANOVIC, N. 1999. Water quality evaluation by index in Dalmatia. Water Research 33(16): 3423 - 40.

VAROL M., AND B. SEN. 2012. Assessment of nutrient and heavy metal contamination in surface water and sediments of the upper Tigris River, Turkey. CATENA 92: $1-10$

WUY, H. Y. BAO, D. UNGER, L. S. HERBECK, Z. Y. ZHU, J. ZHANG AND T. C. JENNERJAHN. 2012. Biogeochemical behavior of organic carbon in a small tropical river and estuary, Hainan, China. Continental Shelf Research In Press

ZYADAH ,H. M. 1996. Occurrence of some heavy metals in two aquaculture systems in Damietta Province, Egypt. Journal of Union of Arab Biologist 6 (A) 219 32.

Received November 7, 2012

Accepted April 7, 2013

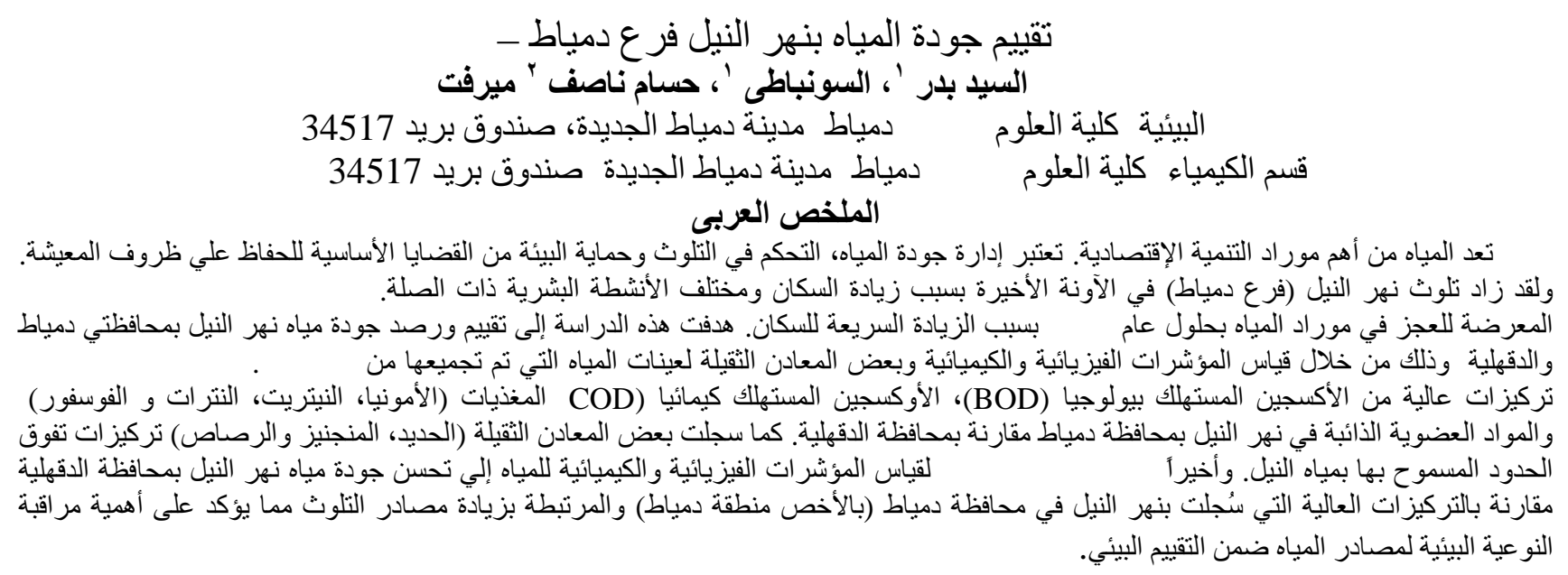



Appendix. Pearson's product moment correlations matrix for water quality parameters of the Nile River, Damietta Branch samples

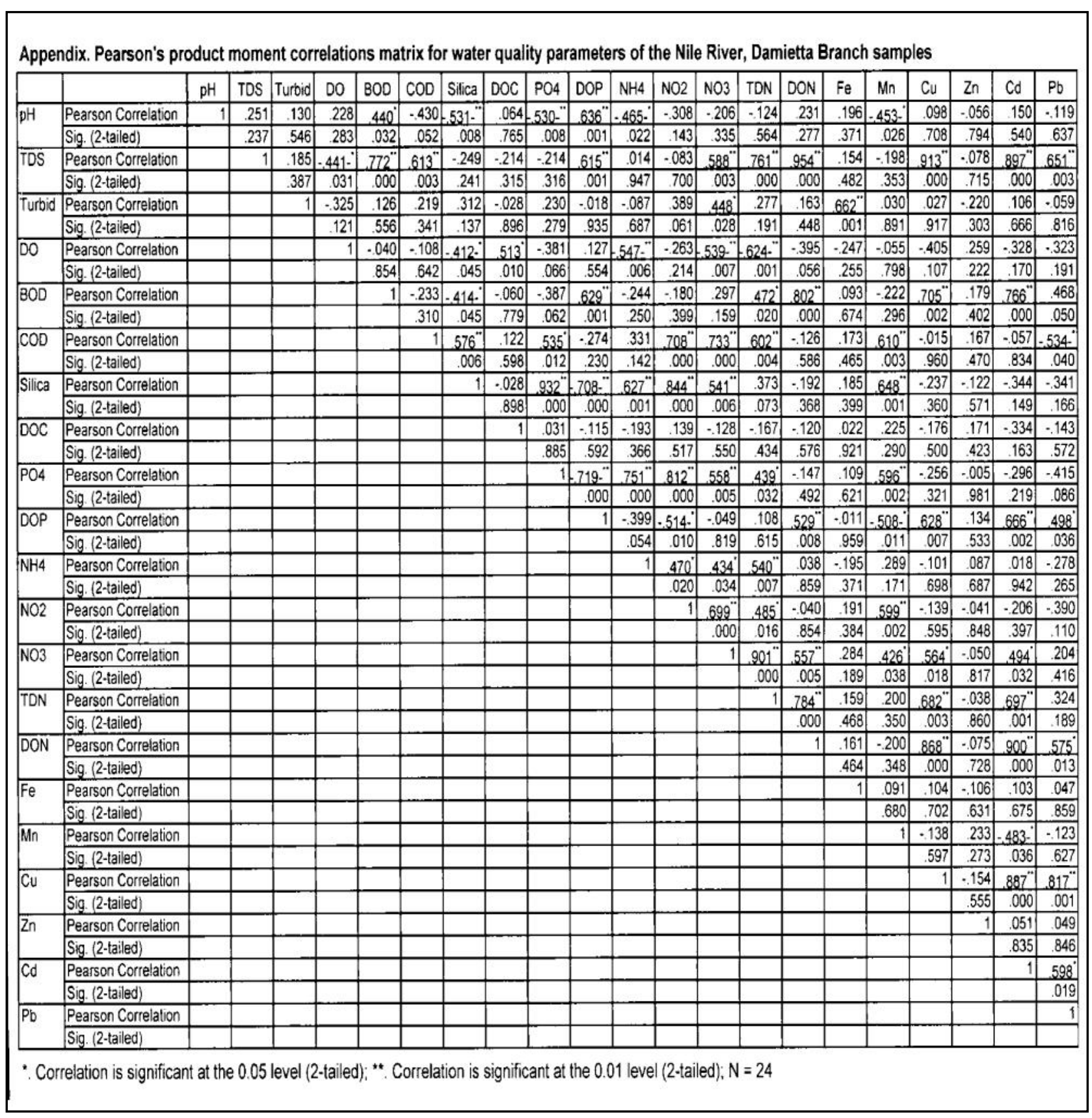

